\title{
KIR2DL3 Gene
}

National Cancer Institute

\section{Source}

National Cancer Institute. KIR2DL3 Gene. NCI Thesaurus. Code C129039.

This gene is involved in the inhibition of natural killer cell-mediated cell lysis. 